FEDERAL RESERVE BANK OF SAN FRANCISCO

WORKING PAPER SERIES

\title{
Did Foreign Direct Investment Put an Upward Pressure on Wages in China?
}

\author{
Galina Hale \\ Federal Reserve Bank of San Francisco \\ Cheryl Long \\ Colgate University
}

May 2008

Working Paper 2006-25

http://www.frbsf.org/publications/economics/papers/2006/wp06-25bk.pdf

The views in this paper are solely the responsibility of the authors and should not be interpreted as reflecting the views of the Federal Reserve Bank of San Francisco or the Board of Governors of the Federal Reserve System. This paper was produced under the auspices for the Center for Pacific Basin Studies within the Economic Research Department of the Federal Reserve Bank of San Francisco. 


\title{
Did Foreign Direct Investment Put an Upward Pressure on Wages in China?
}

\author{
Galina Hale* \\ Federal Reserve Bank of San Francisco \\ Cheryl Long ${ }^{\dagger}$ \\ Colgate University \\ MAY 15, 2008
}

\begin{abstract}
In this paper we study the extent to which foreign direct investment (FDI) could have contributed to recent increase in wages in China. Using a World Bank survey data set of 1500 Chinese enterprises conducted in 2002, we find that the presence of FDI has both direct and indirect effects on wages of skilled workers, while it does not appear to affect wages of production workers. Moreover, we find that the indirect effect of the FDI presence on wages of skilled workers is limited to private firms. We further find that observed quality of skilled workers in state owned enterprises (SOEs) declines in the presence of FDI in the same industry and region. We discuss potential reasons for such discrepancy in the FDI effects on private firms' and SOEs' labor practices. These findings highlight the relevance of labor market institutions in determining FDI spillovers.
\end{abstract}

JEL classification: L33, F23, O17

Keywords: China, Wages, FDI spillovers, SOE, privatization

\footnotetext{
${ }^{*}$ galina.b.hale@sf.frb.org. Hale is grateful to Stanford Center for International Development for financial support and hospitality during work on this project.

${ }^{\dagger}$ cxlong@mail.colgate.edu. Parts of this draft were previously circulated under the title "Labor Market Imperfections and the Effects of FDI Presence in China." Long thanks Hoover Institution for financial support and hospitality during work on this project.

We thank Michele Cavallo, Robert Deckle, Bob Hall, James Harrigan, Wei Li, Tali Regev and the participants of the SITE 2006 workshop and NBER October 2007 China working group meeting for insightful comments. All errors are ours. The views in this paper are solely the responsibility of the authors and should not be interpreted as reflecting the views of the Federal Reserve Bank of San Francisco or any other person associated with the Federal Reserve System.
} 


\section{Introduction}

Both researchers and policy-makers have long touted foreign direct investment (FDI) as an important factor in promoting developing countries' economic growth. However, despite the rapid growth in international capital flows in recent decades, there is no consensus regarding the impact of FDI inflows on domestic firms $]^{1}$ As a result, it is still unclear whether the appropriate government policy is to promote FDI inflows, to restrict them, or to adopt a laissez-faire stance towards them.

One of the reasons that have been cited to explain the failure in finding positive FDI spillovers is the competition effects on domestic firms. Aitken and Harrison (1999), for example, document competition effects in the output market: by competing away market share from domestic firms, foreign firms are believed to impose negative effects on indigenous firms in the host country, which may offset the positive technological spillovers transferred from foreign firms to domestic firms. In this paper, we focus instead on competition effects in the input markets. In particular, foreign firms may compete for labor inputs with indigenous firms on the domestic labor market and drive up the wage bill.

As shown on Figure 1, in China both real FDI capital utilization and real average wage showed an upward trend in the last decade. Of course, the patterns shown in the figure could be due to a multiplicity of changes that have simultaneously occurred in China during the same time period. A more rigorous study showing the competition effects of FDI on domestic labor market requires more disaggregated data. To date, there has been little direct evidence supporting such competition effects on labor markets: While there has been mixed evidence about the direct effect of FDI on wages, i.e. tests of whether foreign invested firms pay higher wages $2^{2}$ to our knowledge there has been little analysis of indirect effects of

\footnotetext{
${ }^{1}$ For a critical evaluation of studies that find no or negative FDI spillovers, see Moran (2007).

${ }^{2}$ Literature on wages in foreign-invested enterprises includes Aitken, Harrison, and Lipsey (1996) study that finds that higher FDI is associated with higher wages in foreign-invested firms; Almeida (2007) and Heyman, Sjöholm, and Tingvall (2007) studies that find no effects for Sweden and Portugal, respectively; Conyon, Girma, Thompson, and Wrights (2002) and Girma and Görg (2007) studies that find some positive
} 
Figure 1: FDI capital utilization and average wages in China

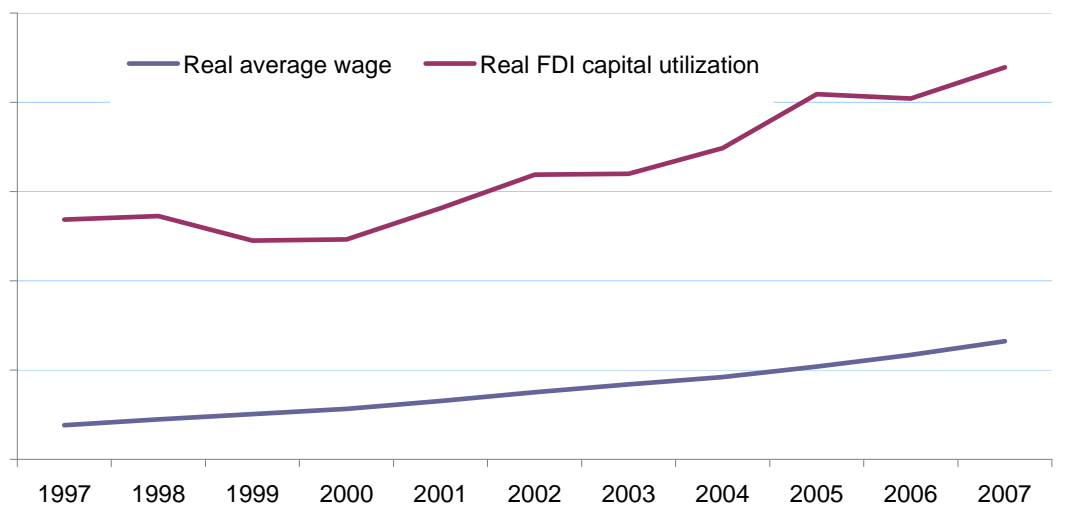

Source: Statistical Yearbook, various issues (Chinese National Bureau of Statistics)

FDI on wages in domestic firms $3^{3}$ We found no studies of FDI effect on quality of labor in foreign invested and domestic firm.

To fill this gap, in this paper we study both direct and indirect effects of FDI presence on labor market outcomes in China using the World Bank firm survey data. We analyze the pressure that FDI puts on wages and quality composition of labor. We measure direct effects by analyzing differences between foreign invested and domestic firms. We measure indirect effects by studying the effects of FDI presence in the same city and industry on wages and quality of labor in domestic firms. To control for potential endogeneity of FDI, we use instrumental; variables approach.

There are two aspects of Chinese labor market that we need to take into account when analyzing our data and interpreting our results. First, although China, until recently, had a rich endowment of unskilled labor, the shortage of skilled labor is well documented. For

effects in for unskilled wages in the UK; and Lipsey and Sjöholm (2004) study for Indonesia that finds positive effects of FDI on wages. In a related paper, Braconier, Norback, and Urban (2005) study the role of low labor costs is attracting FDI.

${ }^{3}$ Exceptions are Aitken, Harrison, and Lipsey (1996) study of U.S., Mexican, and Venezuelan firms that find no evidence of wage spillovers, Feenstra and Hanson (1997) study of Mexican regions that find positive spillovers of FDI on skilled wages, and Barry, Görg, and Strobl (2005) study of large Irish firms that find differential effects on exporting and non-exporting firms. 
example, according to the Report on Chinese Entrepreneurs issued by the Survey System for Chinese Entrepreneurs in 2003, 80\% of the entrepreneurs surveyed report a shortage of technical personnel, over $50 \%$ report a shortage of managerial personnel, and $74 \%$ report a shortage of sales personnel. Second, personnel practices in state owned enterprises (SOEs) in China are likely to differ dramatically from those in private firms. To account for these two aspects, we study effects on wages and quality of skilled and unskilled labor separately. We also allow for FDI presence to have a different effect on wages and quality of labor in domestic SOEs and private firms.

Broadly speaking, we find that some of the increase in wages in China could indeed be attributed to FDI. However, the competitive pressure from FDI does not affect all types of labor in the same way. In addition, FDI presence affects wages and quality of labor differently in domestically owned private firms and in SOEs. In particular, we don't find direct or indirect effects of FDI on the market for unskilled labor — foreign invested firms do not pay higher wage to production workers than domestic firms, hire workers of the same observed quality, and FDI presence does not seem to have any effect on wages and quality of production workers in domestic firms. In contrast, we find that foreign invested firms pay higher wages to their skilled workers and that the observed quality of skilled workers is higher in foreign invested firms, compared to domestic firms. We also find that larger presence of FDI leads to higher wages of skilled workers in private firms and to lower quality of skilled workers in SOEs, especially relative to private firms. These results are more consistent with labor market competition effects of FDI than with skill-biased technology transfer, a finding similar to that of Zhao (2001).

We contribute to the literature in several ways. First, we use a unique firm-level data set to study the effects of FDI in China, an issue that caught the attention of the literature and the media because of China's record-setting growth and FDI inflows.4 Second, the contrasting outcomes we find for SOEs and for private firms add evidence to the advantages of private

\footnotetext{
${ }^{4}$ For a review of previous studies on FDI spillovers in China, see Hale and Long (2007).
} 
ownership over state ownership documented in previous studies $5^{5}$ Third, our empirical findings suggest that the inability of SOEs to benefit from FDI technological spillovers may be due to the wage constraints that forbid them from hiring high quality skilled labor. To the extent that labor market institutions are restrictive in many developing countries, our findings suggest an explanation for the fact that positive FDI spillovers are more difficult to find in developing countries. Finally, because skilled labor enjoys higher wages and we find positive effects of FDI on wages of skilled workers, our findings speak to the literature on FDI and wage inequality. ${ }^{6}$

The structure of the paper is as follows: Section 2 provides institutional background on FDI and wage policies in China and outlines the implications of wage restrictions on SOEs when they compete with other types of firms in the labor market. Section 3 describes the data and the methodology, and presents the empirical findings. Section 4 discusses the various interpretations of our findings, while Section 5 concludes.

\section{Institutional Background and Implications}

In this section we describe the institutional environment in China that is relevant to our analysis - FDI-related policies and trends as well as differences between private firms' and SOEs' wage and personnel policies.

\subsection{Foreign direct investment and FDI policies in China}

China's FDI policies developed from being restrictive before 1978 to being permissive in the early 1980s, then to being encouraging in the mid-1980s to the mid-1990s, and finally

\footnotetext{
${ }^{5}$ See Megginson and Netter (2001) for a summary of empirical evidence showing superior performance of private firms over SOEs.

${ }^{6}$ Two closely related paper in this respect are Blonigen and Slaughter (2001) which, in contrast to our findings, finds no increase in demand for skilled labor due to inward FDI into the U.S., and Feenstra and Hanson (1997) that do find an increase in demand for skilled labor due to FDI inflows into Mexico.
} 
matured in the mid-1990s to link FDI to domestic development priorities. With the country's accession into the World Trade Organization (WTO) in 2001, substantial changes were made to its FDI policies largely to unify the treatment of domestic and foreign firms. $7^{7}$

Since the beginning of the reform era in the mid-1980s, when FDI was allowed only in a limited number of Special Economic Zones (SEZs), the geographic scope was gradually expanded to cover more coastal cities and regions, and then finally to cover the whole country by the mid-1990s. Along with the expansion of geographic areas open to FDI, government policies toward FDI also evolved from permitting it to encouraging it through favorable treatment in taxes, tariffs, foreign exchange regulations, and licensing requirements. These early measures, largely embodied in the Provisions of the State Council of the People's Republic of China for the Encouragement of Foreign Investment (1986), prompted the rapid growth in FDI inflow into China, especially between the mid-1980s and the mid-1990s. Illustrating the breathtaking speed of FDI growth in China, the annual FDI inflow was $\$ 100$ million in 1979, $\$ 1$ billion in 1984, and then reached close to $\$ 40$ billion in 1995 . As shown in Figure 1, the annual FDI inflow has remained above $\$ 40$ billion since 1995 , while the FDI/GDP ratio has surpassed 3\% since 1992. Between 1994 and 1997, the ratio exceeded $5 \%, 8$

Due to the limited geographic regions open to foreign capital and favorable tax policies in the early stages of China's opening up, FDI was largely concentrated in coastal areas and labor intensive industries. Since the mid-1990s, in addition to further expanding the geographic regions open to foreign investment and maintaining a favorable investment environment, government policies began to focus more on linking FDI to domestic development priorities. For instance, the Provisional Guidelines for Foreign Investment Projects, which took effect in 1995, classified all FDI projects to one of four categories: encouraged, restricted, prohib-

\footnotetext{
${ }^{7}$ See Fung, Iizaka, and Tong (2004) for a detailed review of the trend, policy, and impact of FDI in China.

${ }^{8}$ Dollar, Hallward-Driemeier, and Mengistae (2004) show that the investment climate in China is superior to that of South Asian or Latin American countries and that this advantage helps explain large FDI inflows into China.
} 
Figure 2: FDI inflows into China

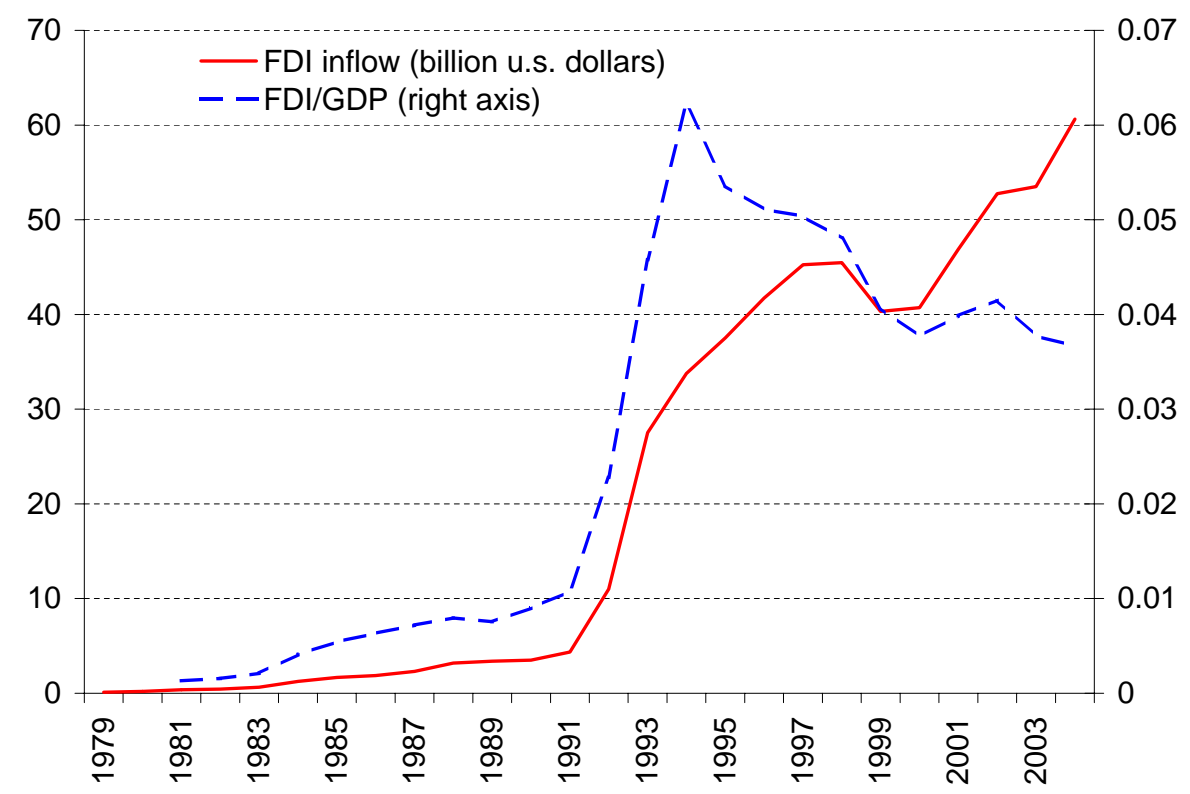

Source: Statistical Yearbook, various issues (Chinese National Bureau of Statistics)

ited, and permitted. Priority was given to FDI in the agriculture, energy, transportation, telecommunications, basic raw materials, and high-technology industries. FDI projects that could take advantage of the rich natural resources and relatively low labor costs in the central and northwest regions were also vigorously encouraged $!^{9}$ As a result, investment from large multinational corporations has increased rapidly and FDI started to shift toward capitaland technology-intensive industries since the mid-1990s. While the coastal areas continue to attract the most FDI inflows, certain inland regions have also become more popular among foreign investors.

In spite of China's great success in attracting FDI, the effects of FDI on domestic firms are far from clear. For instance, Huang (2003) argues that the large FDI inflow into China is accompanied by the repressive policies toward domestic private firms, implying that foreign firms have captured resources, markets, and policy preferences from domestic firms. From

\footnotetext{
${ }^{9}$ The new Guiding Catalogue of Foreign Investment Projects published in 2002 further combined the categories into three: encouraged, prohibited, and permitted.
} 
the viewpoint of the government, the goal in encouraging FDI has been clearly stated from the very beginning to be obtaining advanced technology as well as management skills from foreign partners. But the government's early reluctance to allow solely foreign-owned firms (till the passage in 1986 of the Law of the People's Republic of China on Enterprises Operated Exclusively with Foreign Capital) suggests that it had doubts about FDI spillover effects on domestic firms. In addition, restrictions on domestic sales of foreign-invested firms that existed during much of the pre-WTO period seem to reflect the government's concern that foreign firms might crowd out domestic firms in their competition for domestic market share.

In addition to the potential competition effects on the output market, FDI inflows may also pose competitions to domestic firms on the input markets, especially on the labor markets. The latter competition effects probably did not enter the decision-makers' minds at the time. But our results to be presented below suggest that such competition effects are quite important and thus deserve more consideration in the future.

\subsection{Firm ownership and personnel practices in China}

A firm's ownership type has important effects on employee salaries in China. Liu, Long, and Jing (2007) show that on average, salaries are higher in state owned enterprises (SOEs) than in domestic private firms even after controlling for firm characteristics (such as firm size, age, capital intensity, existence of union, sector and region) as well as employee characteristics (such as education, age, gender, labor productivity, technical level and working experience). However, a typical manager or engineer is paid more in private firms than in SOEs (Kato and Long, 2006). Combined, these patterns imply greater salary dispersion in domestic private firms than in SOEs. In other words, the pay schedule is more compressed in SOEs 10 .

There are at least two potential explanations for such differences, both legacies of the planned economy before 1978: (1) SOEs face constraints in their wage structures, i.e., they cannot

\footnotetext{
${ }^{10}$ Our World Bank data set shows the same patterns, i.e., greater salary dispersion in private firms than in SOEs
} 
pay their skilled employees more due to constraints imposed through government policies and guidelines; and, (2) SOEs have multiple social objectives and thus are not willing to structure their wage scales at the cost of egalitarianism.

Before economic reforms began in the late 1970s, employee compensation in China followed a rigid grid system based on factors that reflected neither firm performance nor individual contributions. The bulk of the industrial labor force was employed in SOEs and their compensation was determined by the region, industry, level of supervising government agency, and the size of the enterprise, as well as the job title, occupation, and seniority of the individual.

In the post-reform era, compensation mechanisms in SOEs oftentimes are still subject to government guidelines that restrict wage differentials among employees and that often set a limit on the maximum salary for executives. For example, both the central government and several provincial governments in China have set or are considering setting limits on the ratio between $\mathrm{CEO}$ salary and production worker compensation. The current limit being contemplated by the central government is 15 , while provinces such as Jiangxi have recently adopted 10 as the ratio limit ${ }^{11}$

As a comparison, the 1996-1997 Tower Perrin Compensation Survey gives the range of CEOworker compensation ratio of 11 for Germany and 24 for the United States. To the extent that these numbers reflect the efficient outcomes of labor market competition in those countries and given the fact that China most likely is in greater need for managerial talents, these limits may impose artificial restrictions on SOEs' ability to hire and retain talent.

Although schemes to circumvent salary caps abound, big salaries for top executives are generally frowned upon by both the government and other employees in the state owned firms. While private firms strive to increase firm value and thus base employee pay on

\footnotetext{
${ }^{11}$ See the March 25, 2005, Issue of China Industry and Commerce Times, and "The Rules for Administrating CEO Compensation in SOEs in Jiangxi Province," government document issued by the Jiangxi State Asset Supervision and Administration Commission (accessed online on July 21, 2006 at http : //jiangxi.jxnews.com.cn/system/2006/07/07/002290697.shtml) .
} 
individual productivity, state owned firms have multiple social objectives to achieve, some of which (such as social stability) are more congruent with more equal pay schemes.

In contrast, private firms in China have always enjoyed more freedom in setting their own compensation policies and they show great flexibility in adopting more effective incentive systems. One telling example is the different pace at which different firms adopt the "yearly salary system" for executive compensation. Consisting of a fixed component (the base salary) and a variable component (the risk salary) that relates the executive's salary to firm performance, this new system resembles the typical cash compensation package in Western firms. The mechanism was initially conceived by the central government as a way to improve SOE performance. In reality, however, the new compensation system was adopted by private firms at a much faster pace, once it proved to provide an effective incentive mechanism for executives ${ }^{12}$ Even in SOEs that have adopted the new compensation system for executives, there is more emphasis on egalitarian concerns.

These explicit and implicit constraints imply a more compressed wage structure in SOEs. As recently as 1999, the highest ratio between CEO compensation and that of an average production worker was 6 among the 40 largest enterprises owned by the central government.13 We are not aware of any data on the ratio between CEO salary and production worker compensation for private Chinese firms in general. But compensation data for private listed firms in China and worker compensation data from the International Labor Organization suggest that the ratio was close to 15 between 1998 and 2002.

Whether it is the inability or the unwillingness on the part of the SOEs, the discussion above shows that in reality private firms in China tend to have a more dispersed and more flexible wage distribution. Whether the more rigid and compressed wage structure in Chinese SOEs is due to explicit restrictions or implicit limitations, they have similar implications on how

\footnotetext{
${ }^{12}$ See Kato and Long (2006) for a detailed discussion of executive salary policies in Chinese firms.

${ }^{13}$ See the "Research report on Chinese manager incentive mechanisms and policies," cited in the Jan. 14, 2002, issue of the Market Daily (accessed online on July 26, 2006 at http ://news.xinhuanet.com/newscenter/2002 - 01/24/content252489.htm) .
} 
these firms compete on the labor market. When faced with firms that are both willing and

able to pay higher wages for workers of higher quality, SOEs may experience difficulty in attracting and retaining quality employees. We now explore the empirical validity of this implication.

\section{$3 \quad$ Empirical evidence}

In this section we will show our findings with respect to the effects of FDI on labor market competition in China. We realize that our findings could have multiple interpretations which we will discuss in the next section. First, we describe our data.

\subsection{Data}

We use data from the Study of Competitiveness, Technology and Firm Linkages conducted by the World Bank in 2001 described in more detail in Hale and Long (2007). The survey consists of two questionnaires, one filled out by the Senior Manager of the firm's main production facility, and the other filled out by the accountant and/or the personnel manager of the firm. The survey collects detailed information on firms and their operation environment. For most of the variables, the firms were requested to provide information as of year 2000 . However, for many accounting measures, information from up to three previous years was also collected. In this study, we use a small portion of the survey that gives accounting information on firms' input (including wages and the composition of the labor force), output, and ownership structure. The list of variables used in our study is presented in the Appendix.

The methodology of the survey is stratified random sampling with the stratification based on subsectors including accounting and related services, advertising and marketing, apparel and leather goods, business logistics services, communication services, consumer products, electronic equipment and components, information technology (IT), and auto parts. A strat- 
ified random sample of 300 establishments is drawn from each of five cities in China: Beijing, Chengdu, Guangzhou, Shanghai, and Tianjin, giving a total sample size of 1500. Table 1 gives the city and sector distribution of firms included in the survey.14

Based on the information on firms' foreign ownership, we construct the measure of FDI presence as follows: For each domestic firm, we identify the city-sector cell where the firm is located. We then compute the weighted average of the largest foreign partner's share in each firm located in the same city-sector, as of 1999, with firm employment as the weight. The average foreign share thus obtained is referred to as the "FDI presence" in the city-sector cell. Our focus, therefore, is the effect of FDI presence within the same geographic location and industry. Table 2 gives the average foreign share by city and industry sector. For the part of the analysis where we study FDI spillovers in the same location but possibly across different industries, the same method is used to compute average foreign share for each city, also presented in Table 2 .

Table 3 shows summary statistics of the variables used in the analysis. Domestic firms with private ownership of less than $20 \%$ are listed as SOEs, while others are listed as private ${ }^{15}$ This split is only done for the purpose of comparing our variables for domestic firms with different ownership, while in the regression analysis that follows, we use a continuous measure of the share of private ownership. The table shows that SOEs are quite different from private firms in many aspects: They tend to be larger and have a longer history; their workers tend to be older and less educated, and tend to get lower wages; and their managers tend to have less foreign work experience. These differences are all statistically significant.

\subsection{Empirical approach}

First we analyze direct effect of FDI on wages and labor quality by estimating differences between domestic and foreign firms, excluding SOEs from our sample, where SOEs are

\footnotetext{
${ }^{14}$ For a detailed description of the survey, see Hallward-Driemeier, Wallsten, and Xu (2003).

${ }^{15}$ This split corresponds most closely to the ownership characterizations provided by the firms.
} 
defined as firms with less than 100 percent of private ownership share. We use a similar specification:

$$
Y_{j i k}=\alpha_{i k}+\beta_{1} F O R_{j i k}+Z_{j i k}^{\prime} \Gamma+\epsilon_{j i k}
$$

where $Y_{j i k}$ is an outcome variable, such as average production worker education, age, or wage, in the firm $j$ operating in industry $i$ and city $k, \alpha_{i k}$ are city-industry fixed effects, $F O R_{j i k}$ is the share of foreign ownership in firm $j$ that operates in industry $i$ and city $k$, $Z_{j i k}$ is a set of firm-level control variables specific to the outcome variable, while $\epsilon_{j i k}$ is a robust error term. The coefficient $\beta_{2}$ on $F O R_{j i k}$ measures the difference between foreign and domestic private firms and is thus the measure of direct effect of foreign direct investment on our outcome variables.

The above specification, if estimated by the OLS, maybe subject to the omitted variable bias, reflecting the "cherry-picking effect" of foreign investment much discussed in the FDI literature: the fact that foreign investors choose to acquire a stake in firms that are already more productive. To address this potential bias, we estimate the same relationship using the instrumental variables approach. Blonigen (2005) argues that multinational corporations make overseas investment for several reasons, including securing access to domestic market, and using cheap local resources, such as labor, to produce for other markets.16 After some experimenting, we found two valid instruments in our data set that are correlated with share of foreign ownership of the firm, but have no direct effect on labor market outcomes for these firms: the share of foreign sales (EXshare) of the firm and the share of transportation cost in the total cost of purchasing supplies (TRcost). Both of these variables are available in our survey data. Using these instruments, we estimate the following system of equations by

\footnotetext{
${ }^{16}$ Empirical studies demonstrating the importance of these factors include Amiti and Smarzynska Javorcik (2008), Blomstrom and Lipsey (1991), and Kravis and Lipsey (1982) (size and access to domestic markets and suppliers); Bagchi-Sen and Wheeler (1989) (population size, population growth, and per capita sales); Coughlin, Terza, and Arromdee (1991) (tax rate and infrastructure); de Mooij and Ederveen (2003) (tax rate); Ma (2006) (access to international market). Studies on location of FDI specific to China include Cheng and Kwanb (2000) and Sun, Tong, and Yu (2002).
} 
generalized method of moments (GMM).

$$
\left\{\begin{aligned}
F O R_{j i k} & =\delta_{i k}+\delta_{1} \text { EX }_{\text {share }} \text { jik }+\delta_{2} \text { TRcostjik }+{\overline{Z^{\prime}}}_{j i k} \Phi+\omega_{j i k} \\
Y_{j i k} & =\alpha_{i k}^{\prime}+\beta_{1}^{\prime} F O R_{j i k}+Z_{j i k}^{\prime} \Gamma+\epsilon_{j i k}
\end{aligned}\right.
$$

To document differences between SOEs and private firms, we restrict our analysis to firms with no foreign partners, and use the following specification:

$$
Y_{j i k}=\alpha_{i k}+\beta_{2} P R_{j i k}+Z_{j i k}^{\prime} \Gamma+\epsilon_{j i k}
$$

where $P R_{j i k}$ is the share of private ownership of the firm $j$ and other variables are the same as defined above. The coefficient $\beta_{2}$ on $P R_{j i k}$ measures the difference between SOEs and private firms.

Finally, to measure spillover effects of FDI on domestic private firms and SOEs, we use the following specification, again limiting our sample to the firms with zero foreign ownership:

$$
Y_{j i k}=\alpha_{i}+\alpha_{k}+\beta_{3} F D I_{i k}+\beta_{4} P R_{j i k}+\beta_{5} F D I_{i k} \cdot P R_{j i k}+Z_{j i k}^{\prime} \Gamma+\epsilon_{j i k},
$$

where $F D I_{i k}$ is a measure of FDI presence in industry $i$ and city $k$ and $\alpha_{i}$ and $\alpha_{k}$ are city and industry fixed effects ${ }^{17}$ The coefficient $\beta_{3}$ measures the effect of FDI presence on firms with zero private ownership, i.e. SOEs, while the sum $\beta_{3}+\beta_{4}$ measure the effect of FDI presence on firms with 100 percent private ownership.

Like our test of the direct impact of foreign investment on labor market outcomes, this test of the effect of FDI presence on labor market outcomes in domestic firms is subject to omitted variables bias, especially when the omitted variables affect the FDI presence and

\footnotetext{
${ }^{17}$ Because our measure of FDI presence does not vary within city-industry cell, we cannot include a full set of city-industry fixed effects, but rather include city and industry fixed effects.
} 
the outcome variable in the same direction. Given that in this case our endogenous variable is defined at city-industry level, and is not firm specific, we need to find instruments defined at the same level. Relying again on the findings related to determinants of FDI location described above, we use the following two instruments for FDI, which are not correlated with cost and quality of labor in domestic firms: the percentage of firms in the industry that exported in year 2000 multiplied by the berth capacity of the city's seaport (Port $* E X$ ) and the average transportation cost as a percentage of sales in the industry multiplied by the sum of population of all other provinces weighted by the inverse of the distance between the provincial capital and the city squared $($ Dist $* T r) .18$

The capacity of the seaport affects the cost of exporting, while the percentage of firms that export serves as a proxy for the importance of exporting in a particular industry. Thus, Port $* E X$ measures the access to overseas market and the attractiveness to FDI of the particular city-industry cell. The sum of population of all other provinces weighted by the square of the inverse of their distance to a city gives a measure of how centrally located the city is, while the average transportation cost as a percentage of sales measures the bulkiness of the industry. Dist $* \operatorname{Tr}$ therefore measures the access to the domestic market and thus the attractiveness to FDI of the city-industry. These two instruments vaguely correspond to the firm-level export share and the transportation cost variables we used above.

Specifically, we estimate, using GMM, the following system:

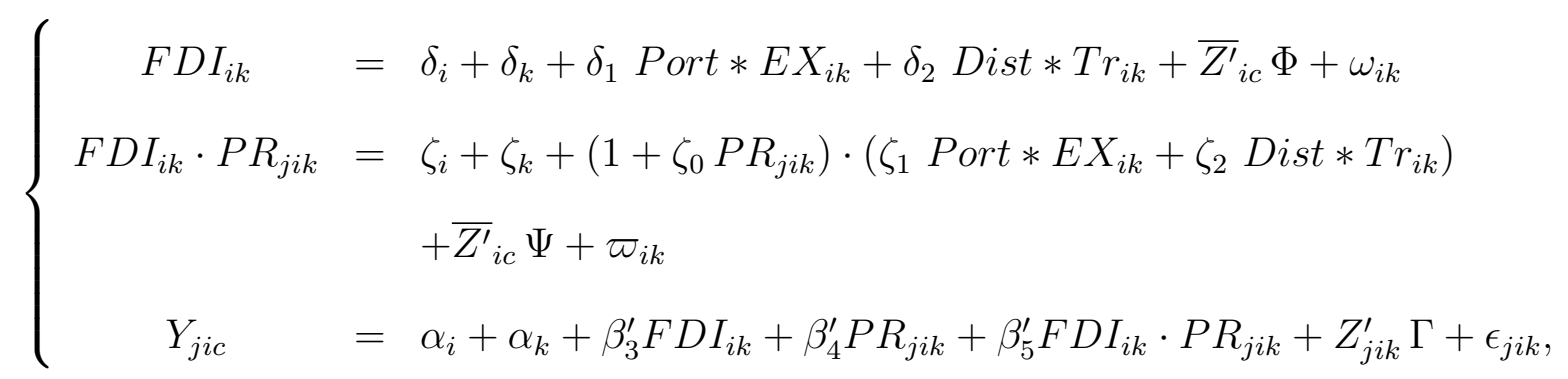

where $\bar{Z}_{i c}^{\prime}$ is a matrix of firm characteristics, averaged for each city-industry cell.

\footnotetext{
${ }^{18}$ See Hale and Long (2007) for the full description and the values of these variables for each city-industry cell.
} 


\subsection{Empirical results}

Table 4 shows results of our study of direct effects of FDI on wages and labor quality. We exclude SOEs from our analysis to abstract from the difference in ownership. ${ }^{19}$ We find that, whether or not we control for observed quality of labor, firms with higher share of foreign ownership share pay higher average wages to their engineers and managers. Part of the wage premium is explained by the higher quality of managers, as the coefficient on private share is smaller once we control for observed quality, while the rest may be due to unobserved variation in quality not controlled for by age and education. Although the point estimate is positive, there is no statistically significant effect of foreign ownership share on the wage of production workers.

In addition, we find that firms with higher share of foreign ownership tend to hire younger workers of all types, as well as more educated managers who are also more likely to have foreign working experience. Taking together, these results show that foreign invested firms seek younger employees (note that we condition on the firm age), better qualified managers, and are willing to pay higher wages to their engineers and managers, but not to their production workers. Thus, higher presence of foreign-invested firms would raise the skilled wage level, but not the unskilled wage.

The above effects are substantial in terms of magnitude, firms with 100 percent foreign ownership would hire engineers and production workers that are on average 2.3 years younger and managers that on average 1.6 years younger, have 8.5 more months of education and are 12 percentage point more likely to have foreign experience, compared to domestic private firms. Managers in fully foreign firms would get paid 51 percent more than in fully domestic private firms, with 9 percentage points due to their observable quality advantage. Finally, engineers in fully foreign firms get on average 30 percent higher wages compared to fully domestic private firms.

\footnotetext{
${ }^{19}$ The reported results exclude all the domestic firms with private ownership share less than $100 \%$. As a robustness test we instead excluded firms according to their legal status and obtained similar results.
} 
Table 5 presents the results of the same set of regressions estimated with instrumental variables by GMM. We find that the effects of foreign ownership on wages, employees age, and managers' foreign experience are qualitatively the same and are much larger in magnitude. The only qualitative difference we find is in the effect of foreign ownership on education, which is now negative for production workers and engineers and positive but not significant for managers. Moreover, the validity of our instruments is rejected in only two regressions: those for engineers' age and foreign experience, while the null of weak instruments is always rejected. Overall, we believe that our OLS results discussed above are not driven by the "cherry-picking" phenomenon, potentially with the exception of results related to employees' education, and that foreign ownership is indeed associated with higher wages and better quality of employees compared to the firms that are $100 \%$ domestically owned.

Before we discuss spillover effects of FDI presence on wages and quality of labor in domestic firms, we document differences in these variables for domestic firms with respect to their ownership structure. Table 6 demonstrates that private firms tend to hire skilled labor of higher quality and pay them higher wages. Specifically, if the share of private ownership is higher, wages paid to engineers and managers, but not to production workers, are higher. We also find that employees of all types tend to be younger, the share of engineers and managers with foreign experience larger, and the managers more educated, while production workers tend to be less educated, if the private share is higher.

To discuss the magnitude of the above differences, we can compare firms with zero private share with those that have 100 percent private ownership share. The coefficients in the regressions reported in Table 6 indicate that wages of engineers are higher in private firms than in SOEs by about 17 percent, while the wages of managers are higher in private firms by about 20 percent. Note that some wage differences are due to differences in quality — when controlling for age, education, and foreign experience, the coefficients on $P R_{j i k}$ in wage regressions for engineers and managers become smaller, with private firms paying 
wage by 12 and 15 percent higher for engineers and managers, respectively, than SOEs. ${ }^{20}$ In addition, private firms hire engineers and managers that are on average 2 and 4 years younger, respectively, when we control for firm age. The differences in education level are modest: private firms hire managers that on average have 4 additional months of education, compared to SOEs.21 The average shares of engineers and managers with foreign experience are 1 and 7 percentage points higher, respectively, in private firms than in SOEs.

We now turn to spillover effects of foreign firm presence on domestic firms. Table 8 presents our main results from IV estimations, while Table 7 presents the results from OLS estimation, which are qualitatively similar, for comparison. The columns of Table 8 give coefficient estimates for private share, FDI presence, and the interaction term between private share and FDI presence along with an F-test of total effect of FDI on $100 \%$ private firms. The rest of the columns report the fit statistics and specification tests. We can see that the null of weak instruments is always rejected while the null of valid instruments is never rejected.

The top panel of Table 8 shows that private firms pay higher wages to both engineers and managers where there is more FDI. In contrast, FDI presence has no effect on the average wages of production workers. The results also show that there are no significant effects of FDI on the wages of skilled or unskilled labor in SOEs.

The bottom panel of Table 8 summarizes the effects of FDI on average labor quality. For unskilled labor such as production workers, FDI presence has no significant effects on either their average age or their average education. In contrast, the presence of FDI reduces the average quality of engineers, exhibited by their average education level, both in SOEs and in private firms. For SOEs, the average education of managers also tends to decrease in the presence of FDI; but such effect is not present for private firms. There is also evidence that the average age of engineers hired by SOEs increases in the presence of FDI, although these

\footnotetext{
${ }^{20}$ The remaining average differences reflect the fact that age, education, and foreign experience only measure some of the quality aspects, with many others not observed by an econometrician.

${ }^{21}$ Note that average education of managers in SOEs is 12.6 years - see Table 5 .
} 
last two effect are not statistically significant.

Two results on quality of managers are a bit different from those on engineers. With higher FDI presence, the average age of managers tends to decrease for private firms, while the percentage of managers with foreign work experience tends to increase for these firms. In other words, the average quality of managers for private firms tends to be higher where FDI is present.

To understand the magnitudes of these effects, we compare the effects of an increase in FDI presence from zero to 20 percent in the city-industry cell on fully private and fully state-owned firms. Such an increase in FDI presence would lead to 60-70 percent increase in wages of both engineers and managers in private firms, but not in SOEs. It would also lower average education of engineers in SOEs and private firms by about 7 months, lower the average age of managers in private firms by 5.7 years, and increase the share of managers with foreign experience in private firms by 18 percentage points.

\subsection{Robustness tests}

The main concern with the data is that the measure of FDI presence is constructed using a small sample of the firms. Thus, we are concerned that one large firm with or without foreign presence will substantially affect the average foreign share we calculate for the city-industry cell. We therefore construct the alternative measure, for five manufacturing sectors only, using the census of manufacturing firms. We are comforted to find that the new measure is very similar to our original one: for the manufacturing sectors the simple correlation coefficient between the two FDI measures is 0.54 , the adjusted $R^{2}$ of the regression of one measure on the other and city and industry fixed effects is 0.84 , and the Spearman rank correlation coefficient is 0.6422

Since the new measure seems to be substantially higher than our original one for three sectors

\footnotetext{
${ }^{22}$ See Hale and Long (2007) for additional details and the tabulations of the alternative measure.
} 
in Guangzhou and one sector in Tianjin, to test whether our results are sensitive to the small differences in the FDI measure, we replace our original measure with the new measure for manufacturing sectors, while keeping the original measure for the service sectors ${ }^{23}$ All our results on labor quality hold both qualitatively and quantitatively. For the wage results, the P-values tend to increase because the new measure of FDI presence has higher variance, while qualitatively our results hold. We recover the statistical significance of the results if we use instead the $\log (1+$ new measure $)$ which better matches the mean and the variance of our original measure.

We attempted alternative definitions of the FDI presence coming from our original data set. First, we used the same measure of FDI presence as in main specification, but for 2000 rather than for 1999. Our results are unchanged. Alternatively, we weighed the FDI share in each firm by the number of years since the firm first acquired a foreign partner, thus giving higher weight to FDI that was around for longer. We found that such modification does not affect our results much. We are thus fairly comfortable with the results reported in our main specification.

We also re-estimated wage regressions controlling for the hiring conditions of the firms, specific to each type of labor, such as minimum age, education, and experience of new hires, as well as the number of job applications per vacancy. While this restricts our sample, we found that our results are robust to including such controls

Finally, because Barry, Görg, and Strobl (2005) show that FDI may have differential effects on wages of exporting and non-exporting firms, we reestimate our regressions controlling for the share of foreign sales of each firm. We find that our results are not affected by the inclusion of this additional control variable.

\footnotetext{
${ }^{23}$ We are unable to estimate the model for manufacturing sector only, because a small number of degrees of freedom is left when the sample is cut by half.
} 


\section{Discussion of empirical findings}

Our empirical findings give an affirmative answer to the question stated in the title of this paper — "Did Foreign Direct Investment Put an Upward Pressure on Wages in China?"

While this particular result is quite straightforward, we also find some subtle and interesting patterns in the way FDI affects China's labor markets. In particular, we find that the upward pressure of FDI on wages is limited to the market for skilled labor, and that while private firms experience competition from foreign invested firms as evidenced by higher wages of skilled workers, SOEs respond to such competition by hiring skilled workers of lower quality. In this section we discuss our interpretations of this patterns.

Our finding that foreign firms pay higher average wages to skilled labor are consistent with the view that better technology used by foreign firms is complementary to skill and makes skilled labor more productive. In particular, we find the results to be more pronounced for managers than for engineers. This is consistent with the belief that foreign firms have superior managerial practices and therefore their managers in particular are more productive. Another potential reason for this finding is that foreign firms seek more productive managers and that age, education, and foreign experience do not fully account for differences in managers' productivity. In the latter case, more talented managers would be hired away from domestic firms and we would observe a decline in quality of managers in domestic firms where FDI presence increases, while the aggregate wage level would not increase. As results in Table 8 demonstrate, we did not observe such an effect, which suggests that FDI is likely to lead directly to an increase in productivity and thus average wages of skilled labor, especially managers.

Our findings with respect to the effect of private ownership share on wages and quality of labor in purely domestic firms are consistent with our discussion of hiring practices in China. In particular, we find that production workers are paid roughly the same in two types of firms, while engineers and managers are paid more in private firms, indicating relatively 
more compressed wage structure in SOEs. As we discussed, this could be due to implicit or explicit wage constraints faced by SOEs in competing with other types of firms or to the inferiority of their skill-complementary factors of production. Our finding that SOEs tend to employ lower quality skilled labor compared to private firms indicates that the wage compression in SOEs is more likely due to implicit or explicit constraints on wages they can pay.

Furthermore, the average quality of managers for private firms tends to be higher where FDI is present. Since there is no robust evidence for deteriorating quality of managers in SOEs, these results seem to suggest that the supply of managers is more elastic than that for engineers. In particular, the inflow of FDI may have increased the pool of managers, especially those with foreign work experience. But it is interesting that only private domestic firms benefit from the larger pool of managerial talent, but not SOEs. Our explanation for the difference is again the wage restriction faced by SOEs.

In light of our above discussion of reasons for wage compression in SOEs and the cited reports on skilled labor shortages in China, we believe our results can be summarized as follows. Consider the impact of foreign firm entry on the labor market in the context of China, where SOEs face explicit or implicit constraints on wages or have inferior technologies that render skilled labor less productive. One potential effect is an increased demand for skilled labor. Since foreign firms are likely to use more skill-intensive technology and due to "greenfield" FDI that increase demand for all factors of production, larger foreign presence in the city would lead to a higher demand for skilled labor. Given that in the short and medium run the supply of skilled labor is very inelastic, this would push the wages of skilled workers up in the city and industry with higher FDI presence. While private firms would have to raise wages of their skilled workers in order to retain them, SOEs might find it difficult because of explicit or implicit wage constraints. As a result, quality of skilled workers in SOEs would decline. 
Of course, this is not the only story that is potentially consistent with our findings. For example, if foreign firms bring superior skill-complementary technology and that superior technology is adopted by domestic private firms but not by SOEs, we would observe similar patterns. While we do not rule out this possibility, we believe that this scenario is less likely because to our knowledge there is no convincing evidence of technological spillovers from FDI in China. In particular, as we document in our related paper (Hale and Long, 2007), we fail to find any positive spillovers in this same data set. Moreover, our finding of a decline in the quality of skilled labor in SOEs when more FDI is present is hard to explain within this scenario.

Overall, our results suggest that skilled labor is scarce and unskilled labor is abundant in China (or at least was abundant at the time the survey was conducted). As a result, higher competition for skilled labor induced by foreign direct investment leads to higher wages of skilled labor both in foreign invested and in domestic private firms that compete with foreign invested firms for skilled labor. SOEs appear to be unable or unwilling to increase the wages they pay to their skilled workers and as a result experience a decline in the quality of their skilled personnel.

\section{Conclusion}

In this paper we found that the FDI presence in China is putting an upward pressure on wages of skilled workers through increased competition in the market for skilled labor. Such competition effects are reflected in an increase in wages that private firms pay to their skilled workers and in a decline in quality of skilled labor in SOEs that appear to be constrained in terms of wages they can pay to their employees. We find no such competition effects in the market for unskilled production workers.

These findings suggest that labor market institutions such as wage constraints have important implications on how FDI affects domestic firms. To the extent that many developing 
countries have rigid labor market conditions, our findings help explain why it is particularly difficult to find positive FDI spillovers in these countries.

As an example, these findings offer one reason for why Hale and Long (2007) and others fail to find positive productivity spillovers from FDI into China, at least for the SOEs. If FDI leads to a lower quality of skilled workers in SOEs, these firms may lack the human capital necessary for absorbing potential technological spillovers. This in turn implies that quicker privatization may be necessary in order to capture potential positive spillovers from FDI.

Moreover, our findings have important implications for inequality in China. In particular, because FDI presence increases wages of better paid skilled workers, but does not have an effect on wages of production workers, more FDI presence is likely to lead to higher income inequality. This is, in fact, consistent with recent trends of a growing rural-urban income inequality, because unskilled labor in China is largely drawn from the pool of rural population. 


\section{References}

Aitken, B., And A. Harrison (1999): "Do Domestic Firms Benefit from Direct Foreign Investment? Evidence from Venezuela," American Economic Review, 90(3), 605-618.

Aitken, B., A. Harrison, and R. E. Lipsey (1996): "Wages and foreign ownership A comparative study of Mexico, Venezuela, and the United States," Journal of International Economics, 40(3-4), 345-371.

Almeida, R. (2007): "The labor market effects of foreign owned firms," Journal of International Economics, 72(1), 75-96.

Amiti, M., and B. Smarzynska Javorcik (2008): "Trade costs and location of foreign firms in China," Journal of Development Economics, 85(1-2), 129-149.

Bagchi-Sen, S., and J. WheEler (1989): "A spatial and temporal model of foreign direct investment in the United States," Economic Geography, 65(2), 113-129, population size, population growth, and per capita retail sales.

Barry, F., H. Görg, and E. Strobl (2005): "Foreign Direct Investment and Wages in Domestic Firms in Ireland: Productivity Spillovers versus Labour-Market Crowding Out," International Journal of the Economics of Business, 12(1), 67-84.

Blomstrom, M., and R. Lipsey (1991): "Firm size and foreign operations of multinationals," Scandinavian Journal of Economics, 93(1), 101-107.

Blonigen, B. A. (2005): "A Review of the Empirical Literature on FDI Determinants," NBER Working Paper, 11299.

Blonigen, B. A., And M. J. Slaughter (2001): "Foreign-Affiliate Activity and U.S. Skill Upgrading," Review of Economics and Statistics, 83(2), 362-76.

Braconier, H., P.-J. Norback, and D. Urban (2005): "Multinational enterprises and wage costs: vertical FDI revisited," Journal of International Economics, 67(2), 446-470.

Cheng, L. K., And Y. K. Kwanb (2000): "What are the determinants of the location of foreign direct investment? The Chinese experience," Journal of International Economics, $51,379-400$.

Conyon, S., S. Girma, S. Thompson, and P. Wrights (2002): "The impact of foreign acquisition on wages and productivity in the U.K.," Journal of Industrial Economics, 50, $85-102$.

Coughlin, C., J. Terza, and V. Arromdee (1991): "State characteristics and the location of foreign direct investment within the United States," Review of Economics and Statistics, 73(4), 675683, tax rate and infrastructure.

De MooiJ, R. A., and S. Ederveen (2003): "Taxation and Foreign Direct Investment: A Synthesis of Empirical Research," International Tax and Public Finance, 10(6), 673-693, tax rate. 
Dollar, D., M. Hallward-Driemeier, and T. A. Mengistae (2004): "Investment Climate and International Integration," WB Policy Research Working Paper 3323.

Feenstra, R. C., And G. H. Hanson (1997): "Foreign Direct Investment and Relative Wages: Evidence from Mexico's Maquiladoras," Journal of International Economics, 42(34), 371-93.

Fung, K. C., H. IIzaka, And S. Y. Tong (2004): "FDI in China: Policy, Recent Trend and Impact," Global Economic Review, 32(2), 99-130.

Girma, S., AND H. GÖrG (2007): "Evaluating the foreign ownership wage premium using a difference-in-differences matching approach," Journal of International Economics, 72(1), $97-112$.

Hale, G., and C. Long (2007): "Are there Productivity Spillovers from Foreign Direct Investment in China?," Pacific Basin Working Paper 2006-13.

Hallward-Driemeier, M., S. J. Wallsten, and L. C. Xu (2003): "The Investment Climate and the Firm: Firm-Level Evidence from China," World Bank Policy Research Working Paper No. 3003.

Heyman, F., F. Sjöholm, and P. G. Tingvall (2007): "Is there really a foreign ownership wage premium? Evidence from matched employer-employee data," Journal of International Economics, 73(2), 355-376.

Huang, Y. (2003): Selling China: Foreign direct investment during the reform era, Cambridge Modern China Series. Cambridge; New York and Melbourne: Cambridge University Press.

Kato, T., and C. Long (2006): "Executive Compensation, Firm Performance, and Corporate Governance in China: Evidence from Firms Listed in the Shanghai and Shenzhen Stock Exchanges," Economic Development and Cultural Change, 54(4).

KRAVIS, I., AND R. LIPSEY (1982): "The location of overseas production and production for export by U.S. multinational firms," Journal of International Economics, 12(3/4), 201-223, domestic market size.

LiPSEY, R., AND F. SJÖHOlm (2004): "Foreign direct investment, education and wages in Indonesian manufacturing," Journal of Development Economics, 73(1), 415-422.

LiU, L., C. Long, And R. Jing (2007): "Effects of Firm Ownership on Employment Compensation," manuscript.

MA, A. C. (2006): "Geographical Location of Foreign Direct Investment and Wage Inequality in China," The World Economy, 29(8), 1031-1055, access to international market.

Megginson, W. L., And J. M. Netter (2001): "From state to market: A survey of empirical studies on privatization," Journal of Economic Literature, 39, 321-389. 
Moran, T. H. (2007): "How to Investigate the Impact of Foreign Direct Investment on Development, and Use the Results to Guide Policy," Paper prepared for the Brookings conference.

Sun, Q., W. Tong, AND Q. YU (2002): "Determinants of foreign direct investment across China," Journal of International Money and Finance, 21, 79-113.

ZhaO, Y. (2001): "Foreign Direct Investment and Relative Wages: The Case of China," China Economic Review, 12(1), 40-57. 


\section{Appendix. Variables used in this study}

In this study, we use a small portion of the survey that gives information on firms' input, output, as well as foreign ownership. In particular, we use the following variables directly or constructed from the survey, with all values referring to year 2000 unless indicated otherwise:

Capital input: Value of fixed assets in year 2000 RMB, used in logs.

Labor input: Number of employees in the firm, used in logs.

Capital/Labor: Capital intensity of the firm, measured as the ratio between capital input and labor input.

Firm age: Firm's age.

Average education: Average education level of production workers, engineering, and managerial personnel in the firm, in years of schooling.

Average age: Average age of production workers, engineering, and managerial personnel in the firm, in years.

Average foreign experience: Average foreign experience of engineering and managerial personnel in the firm, in years.

Transportation cost: Transportation expenses divided by sales.

Industry: Industry sector of the firm, a categorical variable $1,2, \ldots, 10$.

City: City where the firm is located, a categorical variable $1,2, \ldots, 5$.

Largest foreign partner: The share of the largest foreign partner in firm's ownership in 1999.

Private ownership share: Total share of private ownership, including portfolio investment in 1999.

Foreign ownership share: Total share of foreign ownership, including portfolio investment in 1999.

Share of foreign sales: Foreign sales divided by total sales in 1999.

Transportation cost of supplies: Share of transportation cost in the total cost of supplies purchased in 1999.

We use the following variables from outside of our survey data to construct instruments for FDI presence:

Port berth: The total number of berths (including both productive and non-productive) in the port located by the city (valued at 0 if the city has no port), obtained from Chinese Statistical Yearbook 2001, National Bureau of Statistics.

Distance between cities: The distance between the capital city of each province or autonomous region and the cities in our sample, obtained from the official web site of the China National Materials, Storage and Transportation Corporation ${ }^{24}$

Provincial population: The population of each province or autonomous region, obtained from Chinese Statistical Yearbook 2001, National Bureau of Statistics.

\footnotetext{
${ }^{24}$ http://www.cmst.com.cn/mileage/mileage.asp last accessed on January 29, 2007.
} 
Table 1: Distribution of Foreign and Domestic Firms

\begin{tabular}{lcccc}
\hline \hline & All & Foreign & Domestic & Private share $^{a}$ \\
\hline $\begin{array}{l}\text { Number of firms } \\
\text { by city: }\end{array}$ & & & & 1118 \\
1. Beijing & 300 & 75 & 225 & 0.31 \\
2. Chengdu & 300 & 32 & 268 & 0.39 \\
3. Guangzhou & 300 & 84 & 216 & 0.46 \\
4. Shanghai & 300 & 122 & 178 & 0.16 \\
5. Tianjin & 300 & 69 & 231 & 0.39 \\
by industry: & & & & \\
1. Accounting etc. & 104 & 11 & 93 & 0.41 \\
2. Advertising and marketing & 89 & 15 & 74 & 0.39 \\
3. Apparel and leather & 222 & 63 & 159 & 0.36 \\
4. Business logistics services & 110 & 22 & 88 & 0.14 \\
5. Communication services & 71 & 3 & 68 & 0.12 \\
6. Consumer products & 165 & 40 & 125 & 0.39 \\
7. Electronic components & 203 & 77 & 126 & 0.36 \\
8. Electronic equipment & 192 & 65 & 127 & 0.37 \\
9. IT services & 128 & 21 & 107 & 0.49 \\
10. Vehicles and parts & 216 & 65 & 151 & 0.37 \\
\hline$a$ For domestic firms only & & & & \\
\hline \hline
\end{tabular}

Table 2: FDI presence by city and industry sector in 1999

\begin{tabular}{lcccccc}
\hline \hline & & & & & & \\
Sector, city & Beijing & Chengdu & Guangzhou & Shanghai & Tianjin & Overall \\
\hline & & & & & & \\
Accounting and related services & 0.186 & 0.000 & 0.011 & 0.000 & 0.022 & 0.048 \\
Advertising and marketing & 0.036 & 0.008 & 0.013 & 0.095 & 0.193 & 0.074 \\
Apparel and leather goods & 0.162 & 0.009 & 0.212 & 0.174 & 0.311 & 0.172 \\
Business logistics services & 0.006 & 0.000 & 0.032 & 0.040 & 0.044 & 0.024 \\
Communication services & 0.000 & 0.008 & 0.000 & 0.000 & 0.008 & 0.003 \\
Consumer products & 0.097 & 0.061 & 0.108 & 0.185 & 0.324 & 0.161 \\
Electronic components & 0.149 & 0.038 & 0.207 & 0.302 & 0.458 & 0.231 \\
Electronic equipment & 0.253 & 0.014 & 0.065 & 0.353 & 0.240 & 0.189 \\
Information technology services & 0.052 & 0.068 & 0.020 & 0.154 & 0.009 & 0.054 \\
Vehicles and vehicle parts & 0.123 & 0.096 & 0.125 & 0.238 & 0.121 & 0.139 \\
\hline
\end{tabular}


Table 3: Summary statistics

\begin{tabular}{|c|c|c|c|c|}
\hline \multirow[b]{2}{*}{ Variable } & \multicolumn{2}{|c|}{ Domestic } & \multirow[b]{2}{*}{ Diff. } & \multirow[b]{2}{*}{ Foreigr } \\
\hline & Mean (SOE) & Mean(private) & & \\
\hline Log of Wage (prod.worker) & 2.07 & 2.01 & 0.06 & 2.37 \\
\hline Log of Wage (engineer) & 2.52 & 2.70 & $-0.18^{* *}$ & 3.09 \\
\hline Log of Wage (manager) & 2.54 & 2.68 & $-0.14^{*}$ & 3.16 \\
\hline Age (prod. worker) & 34.6 & 30.5 & $4.0^{* * *}$ & 29.1 \\
\hline Age (engineer) & 37.5 & 34.2 & $3.4^{* * *}$ & 32.8 \\
\hline Age (manager) & 39.2 & 35.9 & $3.3^{* * *}$ & 35.1 \\
\hline Education (prod.worker) & 9.84 & 9.56 & $0.28^{* *}$ & 9.78 \\
\hline Education (engineer) & 13.1 & 13.5 & $-0.32^{* * *}$ & 13.6 \\
\hline Education (manager) & 12.6 & 12.7 & $-0.19^{*}$ & 13.1 \\
\hline Engineers with foreign experience & 0.004 & 0.11 & $-0.006^{* *}$ & 0.020 \\
\hline Managers with foreign experience & 0.030 & 0.064 & $-0.034^{* * *}$ & 0.15 \\
\hline Skill ratio & 0.31 & 0.36 & $-0.056^{* * *}$ & 0.35 \\
\hline Wage spread & 0.44 & 0.58 & $-0.14^{* *}$ & 0.66 \\
\hline Firm age & 23.7 & 9.92 & $13.8^{* * *}$ & 8.30 \\
\hline Log of capital stock & 9.63 & 8.21 & $1.42^{* * *}$ & 10.0 \\
\hline Log of labor force & 5.60 & 4.76 & $0.84^{* * *}$ & 5.4 \\
\hline Observations $^{a}$ & 326 & 792 & & 382 \\
\hline \multicolumn{5}{|c|}{$\begin{array}{l}\text { Note: } \mathrm{SOE} \text { is defined as private share }<1, \text { private }=\operatorname{not}(S O E) \\
* \text { significant at } 10 \% ; * * \text { significant at } 5 \% ; * * * \text { significant at } 1 \%\end{array}$} \\
\hline
\end{tabular}


Table 4: Differences between foreign and domestic private firms. OLS

\begin{tabular}{|c|c|c|c|c|c|}
\hline Dependent var. & $\beta$ (foreign share) & Robust S.e. & Controls & Adj.R ${ }^{2}$ & N.(obs) \\
\hline \multicolumn{6}{|l|}{ Wage } \\
\hline \multicolumn{6}{|l|}{ Log (average wage) } \\
\hline production workers & 0.16 & $(0.12)$ & $\log (\mathrm{K} / \mathrm{L})$ & 0.06 & 791 \\
\hline engineers & $0.29 * *$ & $(0.13)$ & $\log (\mathrm{K} / \mathrm{L})$ & 0.12 & 832 \\
\hline managers & $0.50^{* * *}$ & $(0.11)$ & $\log (\mathrm{K} / \mathrm{L})$ & 0.15 & 1075 \\
\hline production workers & 0.14 & $(0.13)$ & $\log (\mathrm{K} / \mathrm{L})$, quality $^{b}$ & 0.06 & 776 \\
\hline engineers & $0.24^{*}$ & $(0.13)$ & $\log (\mathrm{K} / \mathrm{L})$, quality $^{b}$ & 0.12 & 801 \\
\hline managers & $0.36^{* * *}$ & $(0.12)$ & $\log (\mathrm{K} / \mathrm{L})$, quality $^{b}$ & 0.16 & 1017 \\
\hline \multicolumn{6}{|l|}{ Labor quality } \\
\hline \multicolumn{6}{|l|}{ Avg. age } \\
\hline production workers & $-2.33^{* * *}$ & $(0.79)$ & $\log (K)$, firm age & 0.33 & 782 \\
\hline engineers & $-2.32^{* * *}$ & $(0.76)$ & $\log (K)$, firm age & 0.26 & 837 \\
\hline managers & $-1.63^{* *}$ & $(0.70)$ & $\log (K)$, firm age & 0.22 & 1071 \\
\hline \multicolumn{6}{|l|}{ Avg. education } \\
\hline production workers & 0.15 & $(0.19)$ & $\log (K)$ & 0.21 & 782 \\
\hline engineers & 0.11 & $(0.17)$ & $\log (K)$ & 0.20 & 839 \\
\hline managers & $0.73^{* * *}$ & $(0.15)$ & $\log (\mathrm{K})$ & 0.28 & 1074 \\
\hline \multicolumn{6}{|c|}{ Avg. foreign experience } \\
\hline engineers & 0.009 & $(0.007)$ & $\log (\mathrm{K})$ & 0.12 & 815 \\
\hline managers & $0.12^{* * *}$ & $(0.033)$ & $\log (K)$ & 0.09 & 1027 \\
\hline
\end{tabular}

* significant at $10 \% ; * *$ significant at $5 \% ; * * *$ significant at $1 \%$

${ }^{b}$ quality controls include average age, average age squared, and average education of the relevant group as well as controls for foreign experience for engineers and managers

Estimated by OLS. City*sector fixed effects included in all regression

Sample limited to private firms 
Table 5: Differences between foreign and domestic private firms. IV

\begin{tabular}{|c|c|c|c|c|c|}
\hline Dependent var. & $\beta$ (foreign share) & Robust S.e. & P-value $(1)^{a}$ & P-value $(2)^{b}$ & N.(obs) \\
\hline \multicolumn{6}{|l|}{ Wage } \\
\hline \multicolumn{6}{|l|}{ Log (average wage) } \\
\hline production workers & 0.72 & $(0.46)$ & 0.00 & 0.18 & 778 \\
\hline engineers & $1.12^{* *}$ & $(0.51)$ & 0.00 & 0.84 & 820 \\
\hline managers & $1.92^{* * *}$ & $(0.53)$ & 0.00 & 0.79 & 1059 \\
\hline production workers & 0.92 & $(0.56)$ & 0.00 & 0.24 & 764 \\
\hline engineers & $1.00^{* *}$ & $(0.49)$ & 0.00 & 0.94 & 792 \\
\hline managers & $1.71^{* * *}$ & $(0.63)$ & 0.00 & 0.77 & 1004 \\
\hline \multicolumn{6}{|l|}{ Labor quality } \\
\hline \multicolumn{6}{|l|}{ Avg. age } \\
\hline production workers & $-23.5^{* * *}$ & $(6.70)$ & 0.00 & 0.19 & 770 \\
\hline engineers & $-17.5^{* *}$ & $(6.22)$ & 0.00 & 0.00 & 827 \\
\hline managers & $-21.2^{* * *}$ & $(5.55)$ & 0.00 & 0.13 & 1055 \\
\hline \multicolumn{6}{|l|}{ Avg. education } \\
\hline production workers & $-2.42^{*}$ & $(1.25)$ & 0.00 & 0.27 & 770 \\
\hline engineers & $-1.85^{*}$ & $(1.10)$ & 0.00 & 0.33 & 829 \\
\hline managers & 0.50 & $(0.79)$ & 0.00 & 0.32 & 1058 \\
\hline \multicolumn{6}{|l|}{ Avg. foreign experience } \\
\hline engineers & 0.05 & $(0.05)$ & 0.00 & 0.05 & 806 \\
\hline managers & $0.47^{* * *}$ & $(0.14)$ & 0.00 & 0.52 & 1013 \\
\hline
\end{tabular}

* significant at $10 \%$; ** significant at $5 \%$; *** significant at $1 \%$

${ }^{a}$ Partial F-test for the first stage (H0: weak instruments)

${ }^{b}$ Hansen J-test for over-identification (H0: valid instruments)

Estimated by OLS. City*sector fixed effects included in all regression

Sample limited to private firms. Control variables are the same as in Table 4 
Table 6: Differences between domestic private firms and SOEs

\begin{tabular}{|c|c|c|c|c|c|}
\hline Dependent var. & $\beta$ (private share) & Robust S.e. & Controls & Adj. $R^{2}$ & N.(obs) \\
\hline \multicolumn{6}{|l|}{ Wage } \\
\hline \multicolumn{6}{|l|}{ Log (avg. wage) } \\
\hline production workers & 0.012 & $(0.093)$ & $\log (\mathrm{K} / \mathrm{L})$ & 0.07 & 793 \\
\hline engineers & $0.17^{* *}$ & $(0.080)$ & $\log (\mathrm{K} / \mathrm{L})$ & 0.13 & 828 \\
\hline managers & $0.18^{* * *}$ & $(0.070)$ & $\log (\mathrm{K} / \mathrm{L})$ & 0.14 & 1076 \\
\hline production workers & 0.022 & $(0.10)$ & $\log (\mathrm{K} / \mathrm{L})$, quality $^{b}$ & 0.07 & 778 \\
\hline engineers & 0.10 & $(0.081)$ & $\log (\mathrm{K} / \mathrm{L})$, quality ${ }^{b}$ & 0.13 & 790 \\
\hline managers & $0.13^{*}$ & $(0.074)$ & $\log (\mathrm{K} / \mathrm{L})$, quality $^{b}$ & 0.15 & 1013 \\
\hline \multicolumn{6}{|l|}{ Labor quality } \\
\hline \multicolumn{6}{|l|}{ Avg. age } \\
\hline production workers & $-5.00 * * *$ & $(0.59)$ & $\log (K)$, firm age & 0.38 & 784 \\
\hline engineers & $-2.33^{* * *}$ & $(0.61)$ & $\log (K)$, firm age & 0.27 & 830 \\
\hline managers & $-3.90 * * *$ & $(0.48)$ & $\log (K)$, firm age & 0.27 & 1075 \\
\hline \multicolumn{6}{|l|}{ Avg. education } \\
\hline production workers & $-0.28^{* *}$ & $(0.13)$ & $\log (K)$ & 0.21 & 789 \\
\hline engineers & 0.042 & $(0.12)$ & $\log (\mathrm{K})$ & 0.18 & 831 \\
\hline managers & $0.29 * *$ & $(0.11)$ & $\log (K)$ & 0.25 & 1077 \\
\hline \multicolumn{6}{|l|}{ Avg. foreign experience } \\
\hline engineers & $0.012^{* *}$ & $(0.005)$ & $\log (\mathrm{K})$ & 0.18 & 820 \\
\hline managers & $0.073^{* * *}$ & $(0.013)$ & $\log (K)$ & 0.11 & 1050 \\
\hline
\end{tabular}

* significant at $10 \% ; * *$ significant at $5 \%$; *** significant at $1 \%$

${ }^{b}$ quality controls include avg. age, avg. age squared, and avg. education of the relevant group as well as controls for foreign experience for engineers and managers

Estimated by OLS. City*sector fixed effects included in all regression

Sample limited to domestically owned firms 
Table 7: Effect of FDI on domestic private firms and SOEs. OLS

\begin{tabular}{|c|c|c|c|c|c|c|}
\hline \multirow[b]{2}{*}{ Dependent var. } & \multicolumn{3}{|c|}{ Coefficient on } & \multirow[b]{2}{*}{ Controls } & \multirow[b]{2}{*}{ Adj. $R^{2}$} & \multirow[b]{2}{*}{ N.(obs } \\
\hline & Private shr. & FDI & FDI*Prv.shr. & & & \\
\hline \multicolumn{7}{|l|}{ Wage } \\
\hline \multicolumn{7}{|l|}{ Log (average wage) } \\
\hline production workers & -0.079 & 0.60 & 0.20 & $\log (\mathrm{K} / \mathrm{L})$ & 0.06 & 793 \\
\hline engineers & 0.057 & $1.17^{*}$ & 0.69 & $\log (\mathrm{K} / \mathrm{L})$ & 0.11 & 828 \\
\hline managers & -0.016 & 0.46 & $1.35^{* *}$ & $\log (\mathrm{K} / \mathrm{L})$ & 0.12 & 1076 \\
\hline production workers & -0.075 & 0.58 & 0.25 & $\log (K / L)$, quality $^{b}$ & 0.06 & 778 \\
\hline engineers & 0.008 & $1.33^{*}$ & 0.50 & $\log (\mathrm{K} / \mathrm{L})$, quality $^{b}$ & 0.11 & 790 \\
\hline managers & -0.11 & 0.47 & $1.76^{* * *}$ & $\log (\mathrm{K})$, quality $^{b}$ & 0.13 & 1013 \\
\hline \multicolumn{7}{|l|}{ Labor quality } \\
\hline \multicolumn{7}{|l|}{ Avg. age } \\
\hline production workers & $-4.89 * * *$ & 3.31 & -3.62 & $\log (\mathrm{K})$, firm age & 0.38 & 784 \\
\hline engineers & $-2.62^{* *}$ & 3.22 & 0.56 & $\log (\mathrm{K})$, firm age & 0.27 & 830 \\
\hline managers & $-3.21^{* * *}$ & 1.40 & -7.96 & $\log (\mathrm{K})$, firm age & 0.27 & 1075 \\
\hline \multicolumn{7}{|l|}{ Avg. education } \\
\hline production workers & $-0.47^{*}$ & -0.023 & 0.56 & $\log (\mathrm{K})$ & 0.20 & 789 \\
\hline engineers & -0.066 & -0.324 & 0.83 & $\log (K)$ & 0.17 & 831 \\
\hline managers & 0.046 & -0.896 & $1.95^{*}$ & $\log (K)$ & 0.24 & 1077 \\
\hline \multicolumn{7}{|c|}{ Avg. foreign experience } \\
\hline engineers & 0.003 & -0.027 & 0.036 & $\log (K)$ & 0.001 & 820 \\
\hline managers & $0.049^{* *}$ & -0.001 & $0.30^{* *}$ & $\log (\mathrm{K})$ & 0.08 & 1050 \\
\hline
\end{tabular}

\footnotetext{
* significant at $10 \%$; ${ }^{*}$ significant at $5 \%$; *** significant at $1 \%$. S.e. are clustered on city*sector cells
}

${ }^{b}$ quality controls include avg. age, avg. age squared, and avg. education of the relevant group as well as controls for foreign experience for engineers and managers

Estimated by OLS. City fixed effects and sector fixed effects included in all regression Sample limited to domestically owned firms 


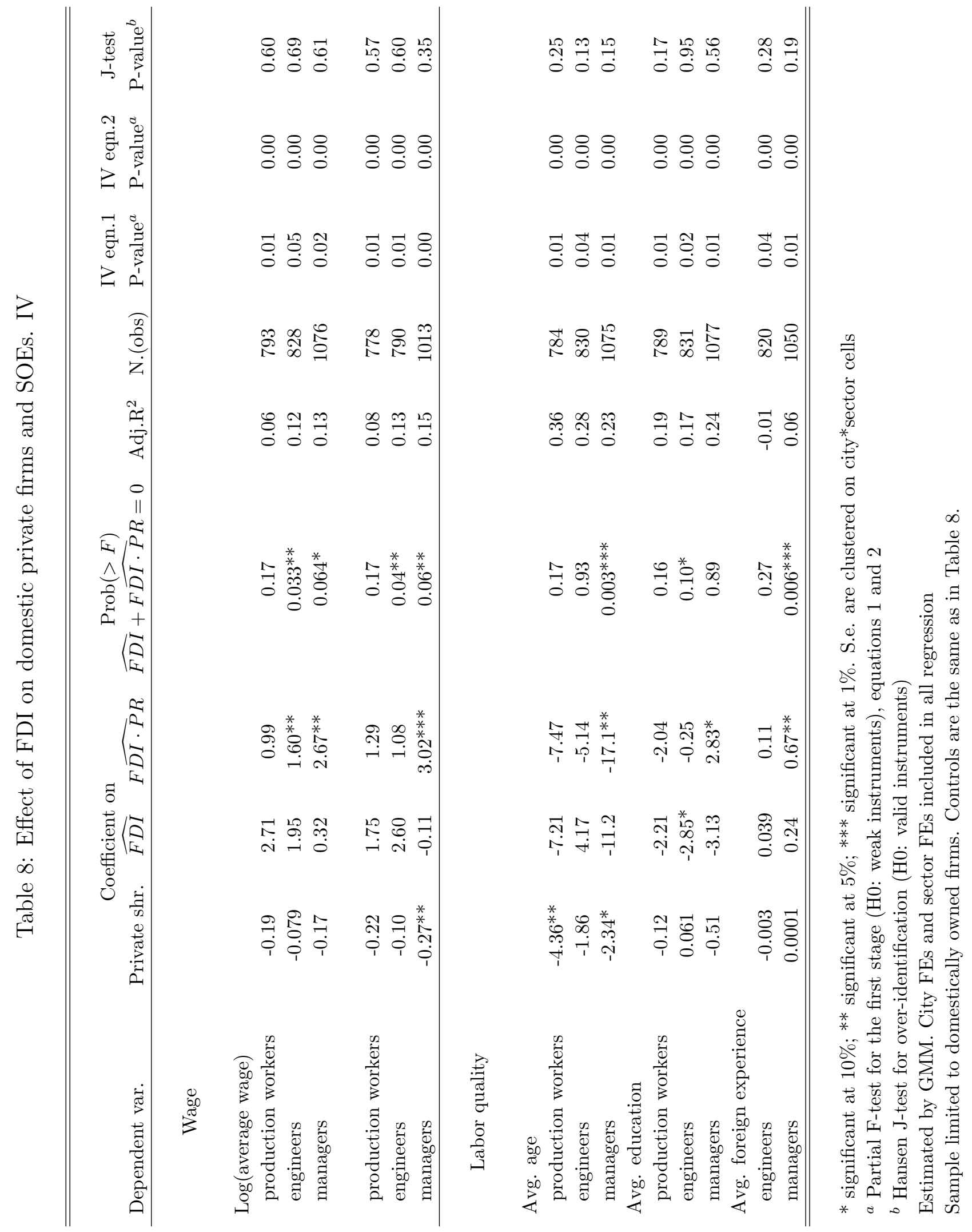

